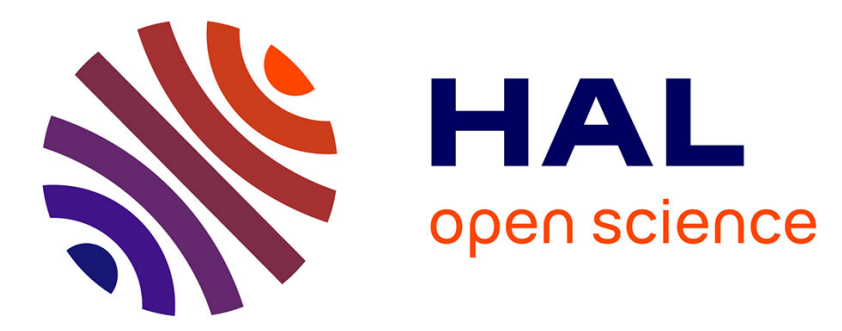

\title{
X-RAY ABSORPTION MEASUREMENTS OF ORGANIC SOLUTIONS OF ORGANOMETALLICS WITH SCINTILLATION COUNTING METHODS
}

T. Sham, R. Holroyd, R. Munoz

\section{- To cite this version:}

T. Sham, R. Holroyd, R. Munoz. X-RAY ABSORPTION MEASUREMENTS OF ORGANIC SOLUTIONS OF ORGANOMETALLICS WITH SCINTILLATION COUNTING METHODS. Journal de Physique Colloques, 1986, 47 (C8), pp.C8-153-C8-157. 10.1051/jphyscol:1986828 . jpa-00226150

HAL Id: jpa-00226150

https://hal.science/jpa-00226150

Submitted on 1 Jan 1986

HAL is a multi-disciplinary open access archive for the deposit and dissemination of scientific research documents, whether they are published or not. The documents may come from teaching and research institutions in France or abroad, or from public or private research centers.
L'archive ouverte pluridisciplinaire HAL, est destinée au dépôt et à la diffusion de documents scientifiques de niveau recherche, publiés ou non, émanant des établissements d'enseignement et de recherche français ou étrangers, des laboratoires publics ou privés. 


\title{
X-RAY ABSORPTION MEASUREMENTS OF ORGANIC SOLUTIONS OF ORGANOMETALLICS WITH SCINTILLATION COUNTING METHODS
}

\author{
T.K. SHAM*, R.A. HOLROYD and R.C. MUNOZ \\ Chemistry Department, Brookhaven National Laboratory, Upton, \\ NY 11973, U.S.A. \\ * and Chemistry Department, The Chinese University of Hong- \\ Kong, Shatin, Hong-Kong
}

\begin{abstract}
We report a new technique with which X-ray absorption measurements of solutions can be made by counting the $X$-ray induced luminescence from the sample. This technique (scintillation yield) involves the addition of a small amount of scintillator to the sample solution. Simultaneous measurements of X-ray absorption spectra of $\left(\mathrm{CH}_{3}\right)_{4} \mathrm{Sn}$ in organic scintillator solutions using photoconductivity and scintillation yield are reported to illustrate the feasibility of this technique.
\end{abstract}

\section{Introduction}

We report the measurement of the $\mathrm{Sn}$ K-edge $\mathrm{X}$-ray absorption spectra of tetramethyltin in toluene (in the presence of a small amount of anthracene) using a liquid scintillation technique. This work is an extention of our recent photoconductivity measurements of $X$-ray absorption in Iiquid hydrocarbons $[1,2]$. The objective is to investigate the correlation of ionization and electron-ion recombination processes in hydrocarbon solutions with the luminescence which is thought to be a result of deexcitation of the molecules following electron-ion recombination.

\section{Experimental}

The experimental apparatus [3] is nearly identical to that of the photoconductivity set-up $[1,2]$ except that an extra port in the sample chamber assembly is now used to house a photomultiplier for luminescence detection. The schematics is illustrated in fig. 1. Fig. 1A is a typical arrangement where a solution cell with parallel-plate electrodes is placed inside the sample chamber which is under dry inert gas atmosphere. The X-ray beam passes through the centers of the first ion chamber, the solution cell and the second ion chamber. This can also be seen at a different angle (fig. 1B) where we look directly into the beam. Four signals, those of the ion chambers $I_{0}, I$, and those of the ion yield, I and the luminescence yield, $I_{\text {f }}$ are monitored simultaneously so that we can correlate the measurements of the absorption, the ionization (conductivity) and the luminescence. The goal of this experiment is to measure these signals as a function of the photon energy at different voltages across the electrodes. Another configuration (fig. 1C) can also be used. In this configuration the liquid sample in a plastic bag can be positioned in place of the conductivity cell [3]. Several samples were used for the preliminary measurements. Here we discuss the results of a solution made of $0.5 \mathrm{ml}\left(\mathrm{CH}_{3}\right)_{4} \mathrm{Sn}$ in $20 \mathrm{ml} 1 \mathrm{~g} / \ell \mathrm{A} / \mathrm{T}$ (anthracene in toluene). 

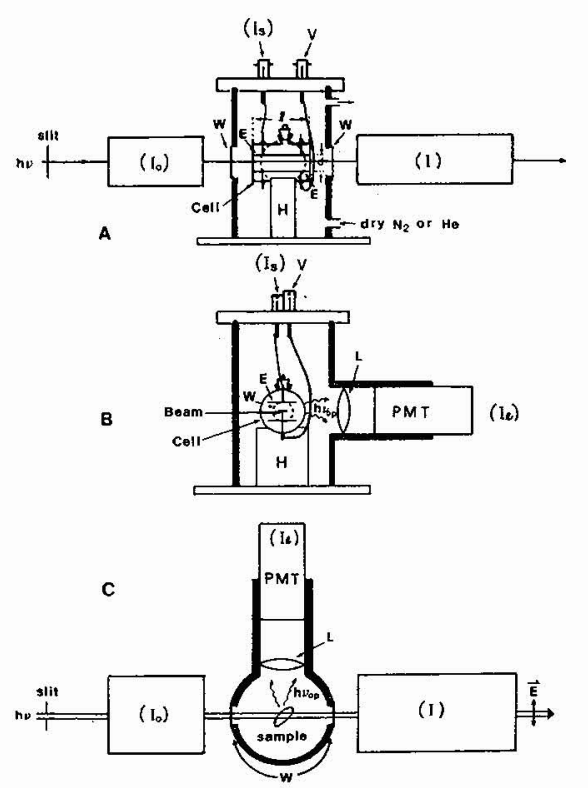

Fig. 1. Schematics for ion and luminescence yield measurements. W: A1/Mylar windows; E: electrodes, $\ell:$ length of the cell, d: electrode separation, $\mathrm{H}$ : cell holder, $\mathrm{V}$ : voltage, $\mathrm{L}$ : focussing lens (see text).

X-ray absorption experiments were performed at the C2 Beamline of the Cornell High Energy Synchrotron Source (CHESS). A horizontal slit ( $0.13 \mathrm{~mm}$ ) was used to maximize the current collection efficiency of the cell which had two $20 \mathrm{~mm}$ long parallel plate electrodes at $3 \mathrm{~mm}$ apart. The photon flux incident upor the sample was within $1-5 \times 10^{8}$ photon/sec throughout the experiment. Ar filled ion chambers were used to monitor the photon beam. The solution cell was biased with a stable power supply and the current (ion yield) was measured with a Keithley amplifier. The luminescent photons were focussed onto an Amperex 1003 PMT which operated at $2900 \mathrm{~V}$ with a dark current of $\sim 6 \mathrm{pA}$ or 60 counts/sec (actual scaler output with amplifier gain set at $10^{8}$ ). The dark current of the toluene solution was tens of pA depending on the applied voltage.

Results and Discussion

The spectra recorded in the Sn-K-edge-voltage-dependent experiment of a 0.5 $\mathrm{ml}\left(\mathrm{CH}_{3}\right) \mathrm{Sn}$ in $20 \mathrm{mI} \mathrm{I} \mathrm{g/l} \mathrm{A/T} \mathrm{solution} \mathrm{are} \mathrm{shown} \mathrm{in} \mathrm{figure} 2$ where we can see 4 sets of spectra obtained in two different modes. The upper series is the luminescence-yield spectra and the lower series is the corresponding ion yield spectra. Several features are immediately noted. First, the ion-yield spectra exhibit a drop across the Sn $\mathrm{K}$ edge. This observation has been previously interpreted as a normal behavior for thick conductivity cells (samples) which absorb nearly all the photons $[1,2]$. Second, for the same incident photon flux the count rate and the resolution of the ion yield spectra increases with the applied voltage while the edge drop decreases. This is because at the edge jump there is a sudden redistribution of the absorption of the incoming photon flux. A large portion of the incoming photon is now absorbed by the $\mathrm{Sn}$ giving rise to low kinetic energy photoelectrons which do not produce many secondary charges and hence yield very small current. Third, the luminescence-yield spectra surprisingly show the same reciprocal pattern (the edge drops) indicating that $I_{\ell}$ is proportional to $I_{s}$ in these thick samples and finally $I_{f}$ is voltage insensitive in contrast ${ }^{s}$ to the $\mathrm{I}_{\mathrm{s}}$ results. A summary of the data are presented in Table 1. 


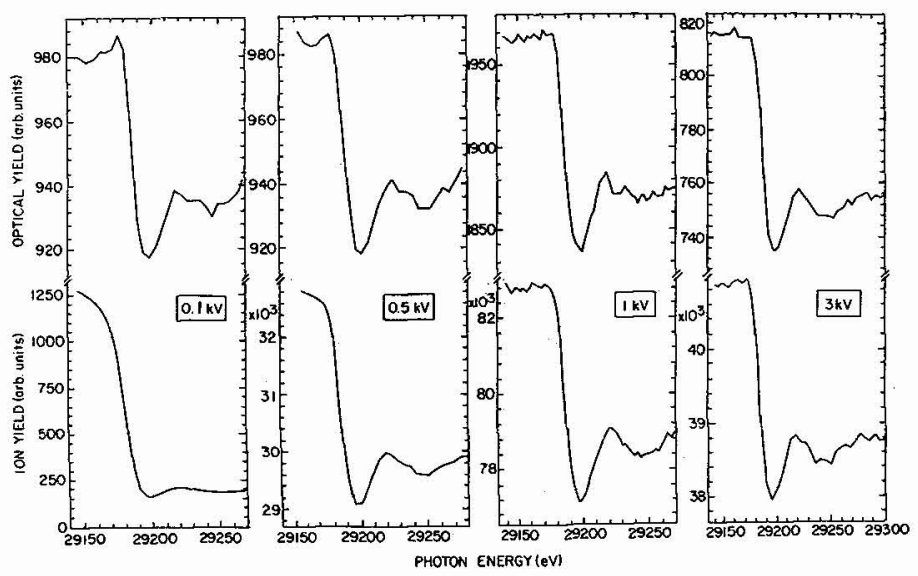

Fig. 2. Luminescence and ion yield spectra ( $\mathrm{Sn} \mathrm{K}$ edge) of the $\left(\mathrm{CH}_{3}\right)_{4} \mathrm{Sn}$ solution at various voltages (see text).

Table 1. Parameters for figure 2.

\begin{tabular}{|c|c|c|c|c|}
\hline $\begin{array}{l}\text { Voltage } \\
\mathrm{kV}\end{array}$ & $\begin{array}{l}\text { Photon flux } \\
10^{8} \text { photon/sec }\end{array}$ & $\begin{array}{l}\text { Relative Yield } \\
I_{c}(b), I_{c}(a)\end{array}$ & $\begin{array}{l}\left.\text { (counts } / s^{*}\right) \\
I_{\ell}(b), I_{\ell}(a)\end{array}$ & $\begin{array}{l}\text { Ratio of } \\
I^{\prime} / I \\
\gamma(b), c^{\prime}\end{array}$ \\
\hline 0.1 & 1.63 & 1200,120 & 927,856 & $0.77,7.1$ \\
\hline 0.5 & 1.54 & 27500,23700 & 918,853 & $0.033,0.036$ \\
\hline 1.0 & 1.60 & 32000,29200 & 930,865 & $0.029,0.030$ \\
\hline 3.0 & 2.14 & 52500,48900 & 1530,1370 & $0.029,0.028$ \\
\hline
\end{tabular}

* for same number of photons absorbed by the solution after background subtraction, (a) and (b) denote the parameters measured above and below the $\mathrm{Sn}$ $\mathrm{K}$ edge respectively.

We now interpret the luminescence yield spectra in terms of the ion yield behavior of the liquid in the cell. Let us first consider an isolated ionization event involving the solvent molecule. The photoelectron that is removed from the molecule will ionize many molecules in its path. The secondary electrons will thermalized at a distance $\underline{r}$ in the solution where the electron and ion are still coulombicly bound (geminate fon pair). The probability for the electron to escape recombination at ambient temperature [4] is

$$
\mathrm{P}=\exp \left(-\mathrm{e}^{2} / \varepsilon \mathrm{kTr}\right)\left(1+\frac{1.112 \times 10^{-4}}{\varepsilon} \mathrm{E}\right)
$$


where $\varepsilon$ is the liquid dielectric constant, $E$ is the external field (V/cm). It can be seen from ( 1 ) that $P$ is finite at zero field and that unless $E$ is large $\left(>10^{3} \mathrm{~V} / \mathrm{cm}\right), P$ primarily depends on $\varepsilon$ and $\underline{r}(\varepsilon$ for toluene is 2.379$)$. The ionization is further complicated by the Auger electrons and fluorescent X-rays. We can qualitatively visualize that the photon slab (beam) produces a thin primary ionization track as it passes through the liquid and secondary ionization produces extra ionization within this track as we11 as above and below the track. In the presence of an electric field, the charges are drawn towards the electrodes. Once they get away from a dense track they will have a very high probability of reaching the electrode hence giving little contribution to the Iuminescence. In situations where the solution contains a small amount of scintillator molecules A, many solvent molecules(S) are left in an excited state, $S^{*}$ (*denotes excited state) through ionization and recombination processes. Solute excitation can occur by excitation transfer from $S^{*}$ to solute:

$$
\mathrm{S}^{*}+\mathrm{A} \longrightarrow \mathrm{S}+\mathrm{A}^{*}
$$

or as a result of charge transfer:

$$
\mathrm{S}^{+}+\mathrm{A} \longrightarrow \mathrm{S}+\mathrm{A}^{+}
$$

followed by neutralization:

$$
\begin{aligned}
& \mathrm{A}^{+}+\mathrm{e}^{-} \longrightarrow \mathrm{A}^{*} \\
& \mathrm{~A}^{*} \mathrm{~A}+\mathrm{h} v
\end{aligned}
$$

These processes result in the emission of optical photons. Since the solvent to solute energy transfer process plays an important role in the scintillation process, organic molecules containing $\pi$-bonds such as toluene with long lived excited state are expected to be considerably better solvents than saturated hydrocarbon such as hexane for the preparation of liquid scintillators.

The most interesting result is that all the luminescence spectra are simlar, and that they bear the resemblence of the ion-yield spectra and are practically insensitive to the applied voltage. This observation seems to indicate that the luminescence arises primarily from the recombination of geminate ion pairs of the solvent which subsequently tranfers the energy to the organic scintillators. Volume recombination of free ions, which is important at zero or low voltage, has no significant effect on the luminescence spectra. This is expected because the free ion yield is much smaller than the geminate yield [2]. Thus we can write

$$
I_{\ell}=\gamma I_{c}
$$

where $\gamma$ is a correlation function.

It is interesting to investigate $\gamma$ under efficient conditions. $\gamma$ values for several cases studied here are listed in Table 1. It appears that $\gamma$ is practically the same for absorption below and above the $\mathrm{Sn}$ edge and is only slightly voltage dependent when the efficiency of the cell is near unity.

\section{Summary}

We have reported simultaneous measurements of $X$-ray induced luminescence and ionization yield of $\left(\mathrm{CH}_{3}\right)_{4} \mathrm{Sn}$ in hydrocarbons using liquid scintillation counting. Although further studies are needed to better characterise this technique, it already appears to be attractive for situations where direct transmission and $x$-ray fluorescence yield techniques are not applicable. 


\section{Acknowledgement}

$\mathrm{X}$-ray measurements were made at CHESS which is supported by US NSF. Research carried out at Brookhaven National Laboratory under contract DE-AC02-76CH00016 with the U.S. Department of Energy and supported by its Division of Chemical Sciences, Office of Basic Energy Sciences.

\section{References}

1. T.K. Sham and R.A. Holroyd, J. Chem. Phys. 80, 1026 (1984); T.K. Sham and R.A. Holroyd in "EXAFS and Near Edge Structure III" Springer-Verlag, Berlin, 1984.

2. R.A. Holroyd, and T.K. Sham, J. Phys. Chem. 89, 2909 (1985).

3. T.K. Sham, R.A. Holroyd and R.C. Munoz. Nucl. Inst. Meth. to be published.

4. R.A. Holroyd and D.F. Anderson, Nucl. Inst. Meth. to be published. 